\title{
Food-based dietary guidelines - the Austrian perspective
}

\author{
Juergen Koenig* and Ibrahim Elmadfa \\ Institute of Nutritional Sciences, University of Vienna, Althanstrasse 14, A-1090 Vienna, Austria
}

\begin{abstract}
Presently, no national dietary guidelines - neither food- nor nutrient-based - exist for Austria. Usually, the recommendations of the German Society of Nutrition are used instead. The determination of national characteristics of nutritional behaviour and food consumption can reveal starting-points for the improvement of nutritional status in Austria. Seven-day weighed records (children and adolescents, $n=2.173$ ) and 24-h-recalls (adults, $n=2.488$ ) were used for the evaluation of nutrient intake and food consumption. For a sub-sample of children and adolescents, results from laboratory assessment of biomarkers were also available $(n=1.400)$. Based on fat intake, the age groups were divided into low fat intake (less than 25 th percentile $=$ $28-34 \%$ fat energy) and high-fat eaters (greater than 75th percentile $=38-45 \%$ fat energy). Approximately $75 \%$ of the Austrian population have fat intakes above $30 \%$ of energy intake, older age groups having a higher prevalence of high fat intakes. Intakes of saturated fatty acids reach $40-46 \%$ of total fat. The usual intake of dietary fibre in the Austrian population is between $17-21 \mathrm{~g} / \mathrm{d}$; some individuals are able to achieve the recommended intakes for dietary fibre, but do not represent a significant majority of the population. The mean intakes of fruits are clearly higher in children and adolescents (10\% of total food intake) than in adults (2-6\%). Differences in the intake of selected nutrients in foods between low and high fat consumers, unexpectedly, did not result in different plasma concentrations of cholesterol, nor did it result in differences in fat soluble vitamins. Therefore, one of the primary dietary guidelines for Austria should be the reduction of fat consumption, which is also associated with increasing intakes of fruits and vegetables, increasing intakes of dietary fibre and decreasing intakes of cholesterol.
\end{abstract}

Food-based dietary guidelines: Austria

The development of dietary guidelines in Austria has a rather short history and in fact did not start until after the establishment of the Institute of Nutritional Sciences at the University of Vienna at the beginning of this decade. The principal problem in the delay of this development has been the lack of adequate data to describe food and nutrient intakes of the Austrian population. Attempts had been made to assess the food consumption based on food balance sheets, but these attempts had not been continued. Thus, Austria adapted the complete pattern of the German recommendations on dietary allowances (Deutsche Gesellschaft für Ernährung 1991a), issued from the German Society of Nutrition, on a nutrient-based level, as well as the subsequent recommendations of this body on a food-based level, entitled 'Ten Rules for a Wholesome Nutrition' ('Zehn Regeln für eine vollwertige Ernährung') (Deutsche Gesellschaft für Ernährung 1991b).

In the past eight years, several studies have been conducted by the Institute of Nutritional Sciences with the primary goal of a country-wide nutrition survey of all relevant groups (infants, children, adolescents, adults, pregnant and lactating women, elderly). These studies were based on the laboratory assessment of nutritional status where possible, and the assessment of nutrient intake by dietary records as well as food frequency questionnaires in all groups studied. All these studies were carried out within the framework of the 'Austrian Study on Nutritional Status' (ASNS). Work on the several sub-studies of the ASNS is still in progress; however, the main parts have been completed and have led to reports for the Austrian government (Elmadfa et al. 1994a, b, Elmadfa \& Zarfl, 1996). The final goal of all these studies will be the evaluation of certain patterns of nutritional behaviour in the Austrian population groups leading to national dietary recommendations based on nutrients for use by health professionals and health politics, and national food-based dietary guidelines for the lay person.

At present the evaluation of all available data reveals similar nutritional behaviour in Austria compared to that in Germany or other mid-European countries. Consequently, there is no reason to establish national food-based dietary guidelines completely different from those existing for

\footnotetext{
*Corresponding author: Dr Juergen Koenig, fax +43131336 773, email juergen.koenig@univie.ac.at
} 
Germany or other European countries and therefore modifications on typical national foods will be sufficient. Some smaller studies with nutritional advice for school children, or pregnant and lactating women, have already shown that the existing food-based dietary guidelines are well accepted by the Austrian population. Recently, the food-guide pyramid from the US Department of Agriculture has been distributed and has been well accepted, but will require some further adaptation to comply with the German 'rules'.

\section{Methods}

All sub-studies conducted within the ASNS include the evaluation of at least one food frequency questionnaire and a $24 \mathrm{~h}$ dietary recall. The sub-study on the nutritional status of Austrian school children included a total of 2173 records from children and adolescents at an age of 6 to 18 years and is based on $7 \mathrm{~d}$ weighed records (Elmadfa et al. 1994c); the sub-study on the nutritional status of healthy

Table 1. Mean daily intakes and standard deviation (SD) of fat, saturated fatty acids, dietary fibre, fruits and vegetables of Austrian children and adolescents

\begin{tabular}{|c|c|c|c|c|c|c|c|}
\hline \multirow[b]{2}{*}{ Age (years) } & & \multicolumn{3}{|c|}{ Percentile } & \multirow[b]{2}{*}{ Mean } & \multirow[b]{2}{*}{ SD } & \multirow[b]{2}{*}{ Guideline } \\
\hline & & 25th & 50th & 75th & & & \\
\hline $4-6$ & $\begin{array}{l}\text { Fat (\%energy) } \\
\text { saturated fatty acids (\%energy) } \\
\text { dietary fibre }(\mathrm{g} / \mathrm{d}) \\
\text { fruits }(\mathrm{g} / \mathrm{d}) \\
\text { vegetables }(\mathrm{g} / \mathrm{d})\end{array}$ & $\begin{array}{l}30 \\
13 \\
13 \\
88 \\
18\end{array}$ & $\begin{array}{r}34 \\
14 \\
17 \\
117 \\
42\end{array}$ & $\begin{array}{r}40 \\
17 \\
21 \\
169 \\
80\end{array}$ & $\begin{array}{r}34 \\
14 \\
18 \\
132 \\
57\end{array}$ & $\begin{array}{l}6 \cdot 2 \\
2 \cdot 9 \\
6 \cdot 7 \\
62 \\
57\end{array}$ & $\begin{array}{l}30 \\
10 \\
23\end{array}$ \\
\hline $7-9$ & $\begin{array}{l}\text { Fat (\%energy) } \\
\text { saturated fatty acids (\%energy) } \\
\text { dietary fibre }(\mathrm{g} / \mathrm{d}) \\
\text { fruits }(\mathrm{g} / \mathrm{d}) \\
\text { vegetables }(\mathrm{g} / \mathrm{d})\end{array}$ & $\begin{array}{r}30 \\
12 \\
13 \\
121 \\
42\end{array}$ & $\begin{array}{r}34 \\
14 \\
17 \\
149 \\
72\end{array}$ & $\begin{array}{r}37 \\
16 \\
22 \\
193 \\
114\end{array}$ & $\begin{array}{r}33 \\
14 \\
18 \\
162 \\
82\end{array}$ & $\begin{array}{l}6 \cdot 2 \\
3 \cdot 3 \\
7 \cdot 2 \\
79 \\
60\end{array}$ & $\begin{array}{l}30 \\
10 \\
25\end{array}$ \\
\hline $10-12$ & $\begin{array}{l}\text { Fat (\%energy) } \\
\text { saturated fatty acids (\%energy) } \\
\text { dietary fibre }(\mathrm{g} / \mathrm{d}) \\
\text { fruits }(\mathrm{g} / \mathrm{d}) \\
\text { vegetables }(\mathrm{g} / \mathrm{d})\end{array}$ & $\begin{array}{r}29 \\
11 \\
14 \\
124 \\
43\end{array}$ & $\begin{array}{r}33 \\
13 \\
19 \\
170 \\
80\end{array}$ & $\begin{array}{r}38 \\
15 \\
24 \\
231 \\
120\end{array}$ & $\begin{array}{r}33 \\
14 \\
20 \\
183 \\
89\end{array}$ & $\begin{array}{r}6 \cdot 5 \\
3 \cdot 1 \\
7 \cdot 9 \\
103 \\
66\end{array}$ & $\begin{array}{l}30 \\
10 \\
28\end{array}$ \\
\hline $13-14$ & $\begin{array}{l}\text { Fat (\%energy) } \\
\text { saturated fatty acids (\%energy) } \\
\text { dietary fibre }(\mathrm{g} / \mathrm{d}) \\
\text { fruits }(\mathrm{g} / \mathrm{d}) \\
\text { vegetables }(\mathrm{g} / \mathrm{d})\end{array}$ & $\begin{array}{r}29 \\
12 \\
15 \\
125 \\
48\end{array}$ & $\begin{array}{r}34 \\
14 \\
20 \\
175 \\
86\end{array}$ & $\begin{array}{r}38 \\
16 \\
25 \\
257 \\
144\end{array}$ & $\begin{array}{r}34 \\
14 \\
21 \\
195 \\
104\end{array}$ & $\begin{array}{r}6 \cdot 9 \\
3 \cdot 3 \\
9 \cdot 4 \\
124 \\
78\end{array}$ & $\begin{array}{l}30 \\
10 \\
30\end{array}$ \\
\hline $15-18$ & $\begin{array}{l}\text { Fat (\%energy) } \\
\text { saturated fatty acids (\%energy) } \\
\text { dietary fibre }(\mathrm{g} / \mathrm{d}) \\
\text { fruits }(\mathrm{g} / \mathrm{d}) \\
\text { vegetables }(\mathrm{g} / \mathrm{d})\end{array}$ & $\begin{array}{r}28 \\
11 \\
13 \\
144 \\
79\end{array}$ & $\begin{array}{r}32 \\
13 \\
19 \\
206 \\
121\end{array}$ & $\begin{array}{r}37 \\
15 \\
26 \\
295 \\
170\end{array}$ & $\begin{array}{r}32 \\
13 \\
21 \\
236 \\
130\end{array}$ & $\begin{array}{l}7 \cdot 1 \\
3 \cdot 1 \\
10 \cdot 5 \\
161 \\
77\end{array}$ & $\begin{array}{l}30 \\
10 \\
30\end{array}$ \\
\hline $19-25$ & $\begin{array}{l}\text { Fat (\%energy) } \\
\text { saturated fatty acids (\%energy) } \\
\text { dietary fibre }(\mathrm{g} / \mathrm{d}) \\
\text { fruits }(\mathrm{g} / \mathrm{d}) \\
\text { vegetables }(\mathrm{g} / \mathrm{d})\end{array}$ & $\begin{array}{r}32 \\
13 \\
12 \\
0 \\
0\end{array}$ & $\begin{array}{r}37 \\
16 \\
16 \\
125 \\
100\end{array}$ & $\begin{array}{r}43 \\
19 \\
22 \\
348 \\
200\end{array}$ & $\begin{array}{r}37 \\
16 \\
17 \\
244 \\
132\end{array}$ & $\begin{array}{r}8.9 \\
4 \cdot 6 \\
7 \cdot 9 \\
347 \\
155\end{array}$ & $\begin{array}{l}30 \\
10 \\
30\end{array}$ \\
\hline $26-35$ & $\begin{array}{l}\text { Fat (\%energy) } \\
\text { saturated fatty acids (\%energy) } \\
\text { dietary fibre }(\mathrm{g} / \mathrm{d}) \\
\text { fruits }(\mathrm{g} / \mathrm{d}) \\
\text { vegetables }(\mathrm{g} / \mathrm{d})\end{array}$ & $\begin{array}{r}32 \\
13 \\
12 \\
0 \\
0\end{array}$ & $\begin{array}{r}38 \\
16 \\
17 \\
50 \\
130\end{array}$ & $\begin{array}{r}43 \\
20 \\
22 \\
250 \\
225\end{array}$ & $\begin{array}{r}38 \\
16 \\
18 \\
176 \\
174\end{array}$ & $\begin{array}{r}8 \cdot 4 \\
4 \cdot 6 \\
10 \cdot 3 \\
248 \\
544\end{array}$ & $\begin{array}{l}30 \\
10 \\
30\end{array}$ \\
\hline $36-45$ & $\begin{array}{l}\text { Fat (\%energy) } \\
\text { saturated fatty acids (\%energy) } \\
\text { dietary fibre }(\mathrm{g} / \mathrm{d}) \\
\text { fruits }(\mathrm{g} / \mathrm{d}) \\
\text { vegetables }(\mathrm{g} / \mathrm{d})\end{array}$ & $\begin{array}{r}33 \\
14 \\
11 \\
0 \\
5\end{array}$ & $\begin{array}{r}38 \\
17 \\
17 \\
53 \\
150\end{array}$ & $\begin{array}{r}44 \\
20 \\
23 \\
300 \\
200\end{array}$ & $\begin{array}{r}38 \\
17 \\
18 \\
204 \\
148\end{array}$ & $\begin{array}{r}8 \cdot 8 \\
4 \cdot 7 \\
9 \cdot 1 \\
297 \\
150\end{array}$ & $\begin{array}{l}30 \\
10 \\
30\end{array}$ \\
\hline $46-56$ & $\begin{array}{l}\text { Fat (\%energy) } \\
\text { saturated fatty acids (\%energy) } \\
\text { dietary fibre }(\mathrm{g} / \mathrm{d}) \\
\text { fruits }(\mathrm{g} / \mathrm{d}) \\
\text { vegetables }(\mathrm{g} / \mathrm{d})\end{array}$ & $\begin{array}{r}34 \\
14 \\
12 \\
0 \\
0\end{array}$ & $\begin{array}{r}39 \\
17 \\
17 \\
0 \\
120\end{array}$ & $\begin{array}{r}45 \\
20 \\
22 \\
223 \\
200\end{array}$ & $\begin{array}{r}39 \\
17 \\
18 \\
133 \\
124\end{array}$ & $\begin{array}{r}8.4 \\
4.5 \\
8 \cdot 0 \\
203 \\
118\end{array}$ & $\begin{array}{l}30 \\
10 \\
30\end{array}$ \\
\hline$>56$ & $\begin{array}{l}\text { Fat (\%energy) } \\
\text { saturated fatty acids (\%energy) } \\
\text { dietary fibre }(\mathrm{g} / \mathrm{d}) \\
\text { fruits }(\mathrm{g} / \mathrm{d}) \\
\text { vegetables }(\mathrm{g} / \mathrm{d})\end{array}$ & $\begin{array}{r}34 \\
14 \\
14 \\
0 \\
50\end{array}$ & $\begin{array}{r}38 \\
17 \\
17 \\
105 \\
150\end{array}$ & $\begin{array}{r}45 \\
21 \\
22 \\
250 \\
200\end{array}$ & $\begin{array}{r}39 \\
18 \\
18 \\
160 \\
145\end{array}$ & $\begin{array}{r}7.9 \\
4.8 \\
6 \cdot 7 \\
203 \\
116\end{array}$ & $\begin{array}{l}30 \\
10 \\
30\end{array}$ \\
\hline
\end{tabular}


Austrian adults included 2488 records from adults at an age of 18 to 60 years. For the group of school children a sub-sample of 1400 individuals with data on the levels of biomarkers for nutritional status is available, but has not been included in the results presented in this paper.

Results from food frequency questionnaires, $24 \mathrm{~h}$ recalls, and $7 \mathrm{~d}$ weighed records, respectively, have been evaluated by computer-aided digitalization of the records and the conversion of the consumed foods into food codes according to the German food composition database (Bundeslebensmittelschlüssel) (Dato Denkwerkzeuge 1995).

Because of the type of food record used, however, it is not possible on an individual level to compare the nutrient supply with recommendations or guidelines. This can only be done at the group level. These limitations are partly due to the mode of coding of the food items in the food composition database used, since this database allows the coding of complete meals without splitting these meals into their recipe components. Consequently, the contribution of rarely consumed food items to the intake of certain nutrients, especially micronutrients, can not be thoroughly estimated. Both limitations, type of food records and special characteristics of the food composition tables, require a minimum sample size to reach a scientifically accurate level of evidence.

For the statistical evaluation of the data given in this report, quartiles, mean and standard deviation of intake of the monitored population groups have been calculated for total fat, saturated fatty acids, fibre, and fruit and vegetables. Because of the limitations previously mentioned, the intake of fruit and vegetables excludes their use as ingredients of mixed dishes such as meat dishes, cherries in cakes, vegetables on pizzas, etc.

\section{Results}

An overview of the intake of nutrients is given in Table 1 for the age groups of the Austrian populations participating in the ASNS. The total contribution of fat to energy intake (Table 1) is higher than the recommended value of $30 \%$ in all age groups of the Austrian population. However, no significant differences can be observed between the age groups, although a tendency to higher intakes of fat can be found with increasing age. Approximately $75 \%$ of the Austrian population have fat intakes above $30 \%$ of energy intake; again, older age groups have a higher prevalence of high fat intakes. Data on the intakes of saturated fatty acids show the same characteristics. Saturated fatty acids intake is higher than the recommended level of one-third of dietary fat (10\% of energy). It reaches $40-46 \%$ of total fat in all age groups.

Dietary fibre is consumed in increasing amounts with increasing age until full nutrition responsibility is reached at an age of $>18$ years, when intakes drop again and remain on a constant and relatively low level of $18 \mathrm{~g} / \mathrm{d}$. Only a minority of the population is able to achieve the recommended intakes for dietary fibre. Most people in Austria do not consume sufficient amounts of this food component.

Table 2. Mean daily nutrient intakes of low-fat eaters (fat consumption below 25th percentile) and high-fat eaters (fat consumption above 75th percentile) in Austrian adults

\begin{tabular}{|c|c|c|c|c|c|}
\hline \multirow[b]{2}{*}{$\%$ Fat energy } & \multicolumn{2}{|c|}{ Age 28-34 } & \multicolumn{2}{|c|}{ Age $38-45$} & \multirow[b]{2}{*}{$P$} \\
\hline & Mean & SD & Mean & SD & \\
\hline cholesterol (mg) & 256 & 107 & 361 & 125 & 0.039 \\
\hline saturated fatty acids ( $\mathrm{g}$ ) & 25 & 10.0 & 37 & 11.0 & 0.063 \\
\hline monounsaturated fatty acids (g) & 20 & 8.0 & 30 & $9 \cdot 0$ & 0.076 \\
\hline energy $(\mathrm{kJ})$ & 7839 & 2933 & 8347 & 2436 & 0.161 \\
\hline sodium chloride $(\mathrm{g})$ & $6 \cdot 1$ & 3.1 & 6.8 & $2 \cdot 4$ & 0.294 \\
\hline total food amount $(\mathrm{g})$ & 1924 & 739 & 1720 & 546 & 0.000 \\
\hline sucrose $(\mathrm{g})$ & 78 & $37 \cdot 8$ & 58 & $26 \cdot 0$ & 0.000 \\
\hline calcium (mg) & 742 & 358 & 751 & 310 & 0.401 \\
\hline iron $(\mathrm{mg})$ & 10 & 4.2 & 11 & 3.5 & 0.109 \\
\hline iodine $(\mu \mathrm{g})$ & 117 & $74 \cdot 2$ & 115 & $57 \cdot 1$ & 0.064 \\
\hline potassium (mg) & 2192 & 1429 & 2165 & 736 & 0.008 \\
\hline magnesium (mg) & 257 & 116 & 250 & 80 & 0.000 \\
\hline sodium $(\mathrm{mg})$ & 2537 & 1279 & 2841 & 1001 & 0.268 \\
\hline phosphorous (mg) & 1382 & 512 & 1426 & 420 & 0.075 \\
\hline zinc (mg) & 8 & 3.5 & 9 & 2.9 & 0.279 \\
\hline retinol ( $\mu$ g equivalents) & 638 & 457 & 766 & 552 & 0.286 \\
\hline$\beta$-carotene (mg) & 1.6 & 1.3 & 1.6 & 1.0 & 0.148 \\
\hline thiamin $(\mu \mathrm{g})$ & 909 & 471 & 1013 & 379 & 0.142 \\
\hline cobalamin $(\mu \mathrm{g})$ & 3.4 & $2 \cdot 7$ & 4.5 & 3.0 & 0.358 \\
\hline riboflavin $(\mu \mathrm{g})$ & 1217 & 616 & 1278 & 494 & 0.043 \\
\hline pyridoxin $(\mu \mathrm{g})$ & 1130 & 568 & 1188 & 413 & 0.005 \\
\hline free folic acid $(\mu \mathrm{g})$ & 97 & $45 \cdot 7$ & 92 & $36 \cdot 7$ & 0.006 \\
\hline calciferoles $(\mu \mathrm{g})$ & 1.4 & $1 \cdot 1$ & 1.9 & $1 \cdot 3$ & 0.007 \\
\hline tocopheroles (mg) & 7.9 & 4.1 & $9 \cdot 1$ & 3.8 & 0.509 \\
\hline ethanol $(\mathrm{g})$ & 0.8 & 2.5 & 0.8 & $2 \cdot 2$ & 0.524 \\
\hline dietary fibre $(\mathrm{g})$ & 18 & 8.7 & 15 & 5.5 & 0.000 \\
\hline protein $(\mathrm{g})$ & 54 & $22 \cdot 2$ & 64 & 19.5 & 0.981 \\
\hline carbohydrates $(\mathrm{g})$ & 254.5 & 95 & 210 & 65 & 0.000 \\
\hline water (q) & 1500 & 609 & 1315 & 453 & 0.000 \\
\hline
\end{tabular}


Interestingly, the consumption of fruits and vegetables becomes more and more important in adolescence, reflecting the higher self-responsibility for nutrition and the increasing interest in the subject's own nutrition. However, this tendency can not be maintained up to and throughout adulthood, since young adults at the age of 19 years appear to lose interest in a 'healthy' diet, suggested by steadily decreasing intakes of fruit and vegetables. This decrease can even lead to findings such as when Austrian adults aged 46-56 years were asked what they consumed the day before, more than $50 \%$ answered that they did not consume any fruit on that day. However, if fruits and vegetables are consumed, relatively high intakes compared to the 36-45 age group have been reported. For the older age groups of adults, again increasing intakes of fruit and vegetables can be found, whereas these intakes are still below the intakes of children and young adults.

It has to be emphasized that the change in methods, from $7 \mathrm{~d}$ weighed records for the school children to $24 \mathrm{~h}$ recalls for the adults, may also have contributed to these observed differences in food intake. This underlines again that it is mandatory to use the same methods of dietary assessment when attempting to compare food intake, both at national and international levels. Further studies are therefore required to clarify the true background of the observed changes in food consumption during adolescence and early adulthood.

According to their fat intake, the different population groups have been classified as high-fat eaters when their fat intake contributed more than $37 \%$ to their daily energy intake (75th percentile), and as low-fat eaters when their fat intake was below $35 \%$ of energy intake (25th percentile). Characteristics of both nutrient intake and food consumption were then calculated by the application of a t-test on the several variables available. Tables 2 and 3 show the results of selected variables. We found that low-fat eaters showed a higher intake of total carbohydrates, sucrose, dietary fibre, potassium, magnesium, and folic acid, and lower intakes of cholesterol, vitamins $\mathrm{B}_{2}, \mathrm{~B}_{6}$, and $\mathrm{D}$, compared to high-fat eaters. Food-based evaluation of the records showed that low-fat eaters consume less butter, margarine, fish, all kind of meat (beef, pork, poultry, meat products), pulses, but consume more cereals, dark bread, milk and milk products, fruits and fruit juices. All other food groups showed no differences between low- and high-fat eaters.

In final analysis, these results are not very surprising: low-fat eaters show typical nutritional behaviour with a lower consumption of animal products leading to a lower consumption of cholesterol. It is, however, quite interesting that low-fat eaters do not show significantly lower cholesterol plasma levels than high-fat eaters $(166 \pm 35$ vs $168 \pm$ $36 \mathrm{mg} / \mathrm{dl}, P=0.611$ ) or lower plasma levels of the fat-soluble nutrients $\alpha$-tocpherol, $\beta$-carotene or phylloquinone (data not shown). Low-fat diets do not bear any risk for developing deficiencies of nutrients that are associated with dietary fats, and can be recommended without any risk at the level of the 25 th percentile. This level is still rather high and above or at least near the presently recommended allowances for fat intake. Thus, first steps should be to reduce the fat intake of all other groups of the population with higher fat intakes than the 25 th percentile on the level of recommendation.
Table 3. Mean daily consumption of food groups of low-fat eaters (fat consumption below 25th percentile) and high-fat eaters (fat consumption above 75th percentile) in Austrian adults

\begin{tabular}{|c|c|c|c|c|c|}
\hline \multirow[b]{2}{*}{$\%$ Fat energy } & \multicolumn{2}{|c|}{ Age 28-34 } & \multicolumn{2}{|c|}{ Age 38-45 } & \multirow[b]{2}{*}{$P$} \\
\hline & Mean & SD & Mean & SD & \\
\hline alcoholic beverages (g) & 35 & 130 & 32 & 120 & 0.569 \\
\hline bread $(\mathrm{g})$ & 175 & 84 & 167 & 70 & $0 \cdot 115$ \\
\hline butter (g) & 8 & 8 & 14 & 12 & 0.000 \\
\hline rice $(\mathrm{g})$ & 43 & 72 & 61 & 73 & 0.062 \\
\hline fish (g) & 34 & 60 & 53 & 80 & 0.000 \\
\hline meat $(\mathrm{g})$ & 111 & 69 & 163 & 88 & 0.001 \\
\hline fresh vegetables $(\mathrm{g})$ & 87 & 76 & 101 & 69 & 0.327 \\
\hline poultry (g) & 64 & 89 & 86 & 108 & 0.002 \\
\hline vegetables (g) & 95 & 77 & 110 & 72 & 0.354 \\
\hline cereals (g) & 843 & 454 & 638 & 330 & 0.000 \\
\hline minced meat $(\mathrm{g})$ & 26 & 54 & 41 & 74 & 0.000 \\
\hline honey $(\mathrm{g})$ & 10 & 15 & 9 & 14 & 0.776 \\
\hline pulses $(\mathrm{g})$ & 24 & 57 & 36 & 75 & 0.000 \\
\hline yoghurt (g) & 129 & 164 & 84 & 117 & 0.000 \\
\hline cheese $(\mathrm{g})$ & 50 & 55 & 50 & 58 & 0.901 \\
\hline coffee $(g)$ & 56 & 106 & 65 & 105 & 0.138 \\
\hline $\operatorname{cocoa}(\mathrm{g})$ & 128 & 153 & 144 & 150 & 0.340 \\
\hline potatoes $(\mathrm{g})$ & 119 & 91 & 133 & 82 & 0.203 \\
\hline snacks $(\mathrm{g})$ & 22 & 53 & 21 & 49 & 0.954 \\
\hline lemonade (g) & 350 & 323 & 267 & 236 & 0.000 \\
\hline margarine $(\mathrm{g})$ & $2 \cdot 6$ & $6 \cdot 0$ & 3.9 & $9 \cdot 1$ & 0.000 \\
\hline milk (g) & 297 & 211 & 294 & 181 & 0.241 \\
\hline milk products (g) & 153 & 154 & 120 & 122 & 0.031 \\
\hline breakfast cereals (g) & 43 & 88 & 25 & 53 & 0.000 \\
\hline noodles $(\mathrm{g})$ & 140 & 141 & 145 & 154 & 0.229 \\
\hline fruits $(\mathrm{g})$ & 223 & 140 & 176 & 109 & 0.003 \\
\hline french fries $(g)$ & 37 & 97 & 47 & 79 & 0.236 \\
\hline fruit juices (g) & 353 & 269 & 217 & 190 & 0.000 \\
\hline salads (g) & 75 & 66 & 82 & 65 & 0.750 \\
\hline dark bread (g) & 89 & 57 & 76 & 47 & 0.002 \\
\hline pork ham (g) & 21 & 30 & 27 & 39 & 0.001 \\
\hline citrus fruits $(\mathrm{g})$ & 159 & 145 & 114 & 114 & $0 \cdot 175$ \\
\hline sweets (g) & 62 & 54 & 61 & 45 & 0.099 \\
\hline tea $(\mathrm{g})$ & 176 & 167 & 157 & 163 & 0.234 \\
\hline wholemeal bread $(\mathrm{g})$ & 28 & 46 & 25 & 40 & $0 \cdot 100$ \\
\hline white bread (g) & 74 & 42 & 73 & 38 & 0.082 \\
\hline fat sausages (g) & 43 & 39 & 75 & 53 & 0.000 \\
\hline lean sausages (g) & 27 & 31 & 36 & 38 & 0.000 \\
\hline sausages total $(\mathrm{g})$ & 52 & 38 & 84 & 53 & 0.000 \\
\hline
\end{tabular}

\section{Conclusion}

As can be seen from the results in Table 3, food-based dietary guidelines in Austria as a first attempt towards improving nutritional status are as simple as that: "eat less fat and fatty foods'. Most other goals of nutrition education - increasing intake of fruits and vegetables, increasing the intake of dietary fibre, decreasing the intake of cholesterol go hand in hand with a lower fat consumption. From a psychological point of view it might, however, be more appropriate to find positive guidelines (like 'you may' instead of 'do not'), leading to food-based guidelines aiming in a similar direction as the 5 -a-day programme.

\section{References}

Dato Denkwerkzeuge \& Institut für Ernährungswissenschaftein der Universität Wien (1995) Österreichischer Bundeslebensmittelschlüssel. Vienna.

Deutsche Gesellschaft für Ernährung (German Society of Nutrition) 
(1991a) Empfehlungen für die wünschenswerte Nährstoffzufuhr. Frankfurt am Main: Umschau Verlag.

Deutsche Gesellschaft für Ernährung (German Society of Nutrition) (1991b) Zehn Regeln für eine vollwertige Ernährung. Frankfurt am Main: Umschau Verlag.

Elmadfa I \& Zarfl B (1996) Lebensmittelverbrauch und Lebensmittelverzehr in Österreich. Vienna: Bundesministerium für Land- und Forstwirtschaft.

Elmadfa I, Zarfl B, Koenig J (1994a) Untersuchungen zum Ernährungsstatus österreichischer Schulkinder. Bericht zum
Forschungsvorhaben des Bundesministeriums für Unterricht und Kunst, GZ 40000/105-III/13/92, Vienna.

Elmadfa I, Godina-Zarfl B, Gruber B, König J, Mayer B, Horacek C, Dichtl M, Szallai M, Rützler H, Kloimüller I, Brandtner D \& Ertl-Huemer D (1994b) Erster Wiener Ernährungsbericht. Vienna: WHO-Projekt 'Vienna - Healthy City'.

Elmadfa I, Godina-Zarfl B, Dichtl M \& König J (1994c) The Austrian Study on Nutritional Status of 6 to 18 Years old Pupils. Bibliotheca Nutritio et Dieta 51, 62-67. 